\title{
À MADAME SAND
}

"Ce roc voûté par art, chef-d'œuvre d'un autre âge,

Ce roc de Tarascon hébergeait autrefois

Les géants descendus des montagnes de Foix,

Dont tant d'os excessifs rendent sûr témoignage."

Ô seigneur Du Bartas! Je suis de ton lignage,

Moi qui soude mon vers à ton vers d'autrefois;

Mais les vrais descendants des vieux Comtes de Foix

Ont besoin de témoins pour parler dans notre âge!

J'ai passé près Salzbourg sous des rochers tremblants,

La Cigogne d'Autriche y nourrit les Milans,

Barberousse et Richard ont sacré ce refuge.

La neige règne au front de leurs pics infranchis;

Et ce sont, m'a-t-on dit, les ossements blanchis

Des anciens monts rongés par la mer du Déluge. 